\title{
E3-ligase Skp2 predicts poor prognosis and maintains cancer stem cell pool in nasopharyngeal carcinoma
}

\author{
Jing Wang ${ }^{1,2, *}$, Ying Huang ${ }^{1, *}$, Zhong Guan ${ }^{3, *}$, Jia-liang Zhang ${ }^{3, *}$, Hong-kai Su ${ }^{1}$, Wei \\ Zhang ${ }^{1,2}$, Cai-feng Yue ${ }^{1,2}$, Min Yan ${ }^{1,2}$, Su Guan ${ }^{4}$ and Quentin Qiang Liu ${ }^{1,2}$ \\ ${ }^{1}$ State key laboratory of oncology in South China, Collaborative Innovation Center of Cancer Medicine, Department of \\ Research Laboratory, Sun Yat-sen University Cancer Center, Guangzhou, China \\ 2 Department of Research Laboratory, Sun Yat-sen University Cancer Center, Guangzhou, China \\ ${ }^{3}$ Department of Otorhinolaryngology, Sun Yat-sen Memorial Hospital, Sun Yat-sen University, Guangzhou, China \\ ${ }^{4}$ School of Bioscience and Biotechnology, South China University of Technology, Guangzhou, China \\ * These authors contribute equally to this work \\ Correspondence to: Jing Wang, email: wangj@sysucc.org.cn \\ Quentin Qiang Liu, email: livq9@mail.sysu.edu.cn \\ Keywords: S-phase kinase associated protein 2 (Skp2), nasopharyngeal carcinoma (NPC), aldehyde dehydrogenase1 (ALDH1), \\ cancer stem cell (CSC) \\ Received: March 24, $2014 \quad$ Accepted: June 29, $2014 \quad$ Published: June 30, 2014
}

This is an open-access article distributed under the terms of the Creative Commons Attribution License, which permits unrestricted use, distribution, and reproduction in any medium, provided the original author and source are credited.

\section{ABSTRACT}

Nasopharyngeal carcinoma (NPC) is one of the severe head and neck carcinomas, which is rare in west countries but has high incidence in Southern Asia especially South China. Although NPC is relatively sensitive to radiotherapy, the prognosis of patients is poor due to the advanced stage at the time of diagnosis. Therefore, it is important to understand the mechanisms involved in tumorigenesis and develop early diagnostic techniques. S-phase kinase associated protein 2 (Skp2) is overexpressed in several human cancers and associates with poor prognosis. However, its function in NPC has not been fully addressed. In this study we found Skp2 was highly expressed in NPC specimen and correlated with poor prognosis. We generated Skp2 knockdown cells to further delineate its role in NPC development. Knockdown of Skp2 partially reduced cell proliferation, promoted cellular senescence, and decreased the population of stem cell like aldehyde dehydrogenase1 positive cells as well as their self-renewal ability. Our study not only interprets the predictive role of Skp2 in the poor prognosis of NPC patients, but also reveals that Skp2 regulates the NPC cancer stem cell maintenance, which shed lights on the target therapy and early diagnosis of NPC in clinical application.

\section{INTRODUCTION}

Nasopharyngeal carcinoma (NPC) is one of the most common head and neck cancers in Southern Asia and Northern Africa, the incidence reaches 25 per 100,000 people which is only $0.5 \sim 2$ per 100,000 people in European and American [1]. The major etiologic factors for NPC are genetic susceptibility, endemic environment factors, and Epstein-Barr Viral infection. Early diagnosis is important for NPC patients since it is sensitive to radiotherapy at the early stage. However, about $30 \%$ to $40 \%$ of NPC patients were diagnosed at advanced stage, which are not response well to treatments and will develop metastasis or recurrence at an average of 4 years.

S-phase kinase-associated protein 2 (Skp2), a member of F-box protein family, is the substrate recognition subunit of Skp1-Cullin-F box protein (SCF) E3 ubiquitin ligase complex [2]. Early reports demonstrated that Skp2 recognizes and targets cell cycle inhibitors $\mathrm{p} 21^{\mathrm{Cip} / \mathrm{WAF}}$ and $\mathrm{p} 27^{\mathrm{Kip} 1}$, leads to their ubiquitination and degradation, and further causes cell cycle progression [3]. Skp2 is overexpressed and associated with poor prognosis in variety of human cancers, including prostate cancer [4], gastric cancer[5], breast cancer [6,7], and liver cancer [8], 
Table 1: Associations between Skp2 level and clinicopathologic characteristics in NPC patients $(\mathbf{n}=95)$.

\begin{tabular}{|c|c|c|c|c|}
\hline \multirow[t]{2}{*}{ Variable } & \multirow[t]{2}{*}{ All cases } & \multicolumn{2}{|l|}{ Skp2 } & \multirow[t]{2}{*}{$p$-value } \\
\hline & & High & Low & \\
\hline \multicolumn{5}{|l|}{ Age } \\
\hline$<44$ & 51 & 21 & 30 & 0.844 \\
\hline$\geq 44$ & 44 & 19 & 25 & \\
\hline \multicolumn{5}{|l|}{ Gender } \\
\hline Male & 69 & 29 & 40 & 0.980 \\
\hline Female & 26 & 11 & 15 & \\
\hline \multicolumn{5}{|l|}{$\begin{array}{l}\text { Histopathologic } \\
\text { characteristics }\end{array}$} \\
\hline Undifferentiated carcinoma & 93 & 40 & 53 & 0.223 \\
\hline Others & 2 & 0 & 2 & \\
\hline \multicolumn{5}{|l|}{ Lymph node status } \\
\hline Positive & 17 & 5 & 12 & 0.242 \\
\hline Negative & 78 & 35 & 43 & \\
\hline \multicolumn{5}{|l|}{ Initial clinical stage } \\
\hline $\mathrm{I}+\mathrm{II}$ & 26 & 10 & 16 & 0.659 \\
\hline III+IV & 69 & 30 & 39 & \\
\hline \multicolumn{5}{|l|}{ Tumor stage } \\
\hline $\mathrm{T}_{1}+\mathrm{T}_{2}$ & 34 & 13 & 21 & 0.769 \\
\hline $\mathrm{T}_{3}+\mathrm{T}_{4}$ & 61 & 27 & 34 & \\
\hline \multicolumn{5}{|l|}{ Recurrence } \\
\hline Yes & 11 & 9 & 2 & 0.005 \\
\hline No & 84 & 31 & 53 & \\
\hline \multicolumn{5}{|l|}{ Metastatic } \\
\hline Yes & 17 & 11 & 6 & 0.037 \\
\hline No & 78 & 29 & 49 & \\
\hline
\end{tabular}

Table 2: Estimated recurrence rate before and after 3 years in our NPC cohort.

\begin{tabular}{|c|c|c|c|c|c|c|}
\hline & \multirow{2}{*}{$\begin{array}{l}\text { Recurrent No. } \\
\text { before } 3 \text { years }\end{array}$} & & & \multirow{2}{*}{$\begin{array}{l}\text { Recurrent No. after } \\
3 \text { years }\end{array}$} & & \\
\hline Skp2 & & $\%$ & p-value & & $\%$ & p-value \\
\hline Low (55) & $0 / 55$ & $0.00 \%$ & 0.007 & $2 / 55$ & $3.64 \%$ & 0.410 \\
\hline High (40) & $5 / 40$ & $12.50 \%$ & & $3 / 40$ & $7.50 \%$ & \\
\hline Total (95) & $5 / 95$ & $5.26 \%$ & & $5 / 95$ & $5.26 \%$ & \\
\hline
\end{tabular}


suggesting the oncogenic role of Skp2 in tumorigenesis. However, the association between Skp2 and NPC development and prognosis still remains unclear [9].

Cancer stem cells (CSCs) have been considered as the origin of tumorigenesis, therapeutic resistance, recurrence and distant metastasis [10-12]. The CSC like side population cells in NPC were first defied by our group with Hoechst 33342 staining [10]. Another functional assay for CSC identification is aldehyde dehydrogenase 1 (ALDH1) staining. Wu et al. firstly found that ALDH1 positive NPC cells express high level of stem cell related proteins like OCT4, Bmi-1, KLF4 and Sox2. These cells have high proliferation rate and differentiation ability, strong colony/sphere formation and migration ability compared with negative counterparts. Multivariate analysis indicates that ALDH1 could be an independent prognostic marker for NPC [13, 14]. Cell surface marker staining is another reliable method for CSC isolation. CD44 is a cell surface proteoglycan and glycoprotein related with body immune reaction $[15,16]$. Stem cell markers OCT4 and Bmi-1 were highly expressed in CD44 positive NPC cells which are resistant to radiotherapy and cisplatin/docetaxel treatment [17]. CD133, another cell surface glycolprotein, is originally reported as the specific marker of normal stem cells. CD133 positive NPC cells exhibited strong self-renewal, proliferation and differentiation ability, as well as the remarkable tumor formation ability in vivo [18].

In this study, we demonstrate that Skp2 is a potential poor prognosis marker for NPC patients, inactivation of Skp 2 decreases the NPC CSC population as well as their self-renewal ability. Our finding not only strengthens the role of Skp2 in the tumorigenesis of NPC but also indicates a potential target for NPC therapy.

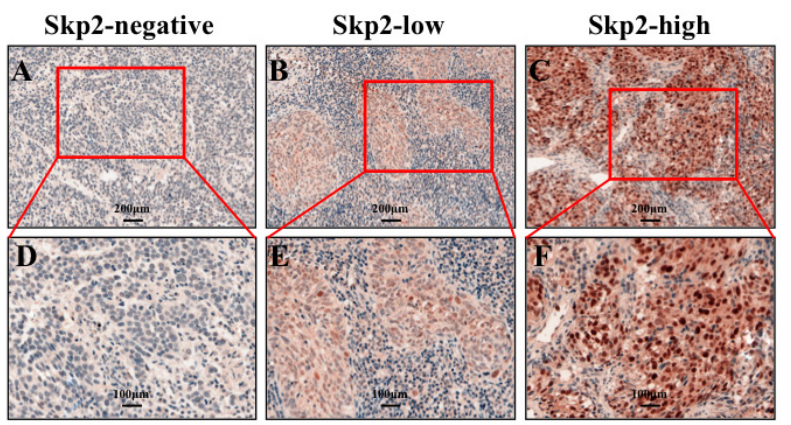

Figure 1: Skp2 expression levels in NPC specimen. A, B and $C$ : Representative images of negative, low and high staining of Skp2, which showed no, few and much brown-yellowish granules in the nuclei of tumor cells $(\times 200)$. D, E and F: The magnification of the indicated field of $\mathrm{A}, \mathrm{B}$ and $\mathrm{C}$ to show the clear staining granules $(\times 400)$.

\section{RESULTS}

\section{High level of Skp2 relates with recurrence and metastasis among NPC clinicophathologic features}

IHC was employed to evaluate Skp2 expression levels in NPC specimens. The immunoreactivity of Skp2 was negative in normal tissue but increased in tumor tissues, where was stained as yellowish brown granules in the nuclei (Fig 1A-F). The signals were collected by microscope and analyzed by Nuance VIS-FL Multispectral Imaging System. We first performed ROC curve analysis (Fig 2A-B, the blue lines indicated the curve of Skp2, the green lines represents the curve of a completely indiscriminate). The cutoff points of OS and PFS from ROC curve analysis were 131.25 and 128.82 respectively. The areas under curve (AUC) were 0.733 and 0.700 for OS and PFS, and both of them were higher than 0.5 (Fig 2AB). Skp2 high expression was examined in $42.1 \%$ (40/95) and low expression was examined in $57.9 \%$ patients (55/95). The association between Skp2 level and clinical features of patients, including age, gender, histopathologic characteristics, lymph node status, initial clinical stage, tumor stage, recurrence and metastasis were summarized in Table 1. High level of Skp2 was positively correlated with recurrence $(p=0.005)$ and metastasis $(p=0.037)$.
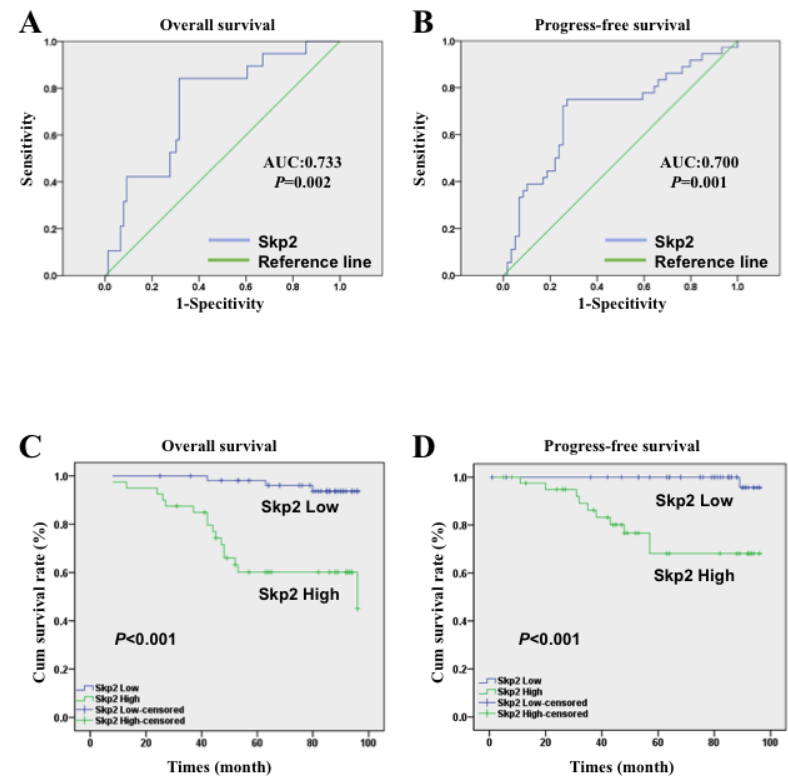

Figure 2: ROC curve and survival analysis of NPC patients with different level of Skp2. A, B: The ROC curve of Skp2 expression level in NPC patients $(\mathrm{n}=95)$, the area under curve was 0.733 and 0.700 , the cutoff value was 131.25 and 128.82 for OS and PFS respectively (AUC: area under the curve). C, D: High level of Skp2 was closely related with poor OS $(p<0.001)$ and PFS $(p<0.001)$ of NPC patients $(n=95)$. 
Table 3: Univariate and multivariate Cox-regression analysis for overall survival in NPC patients $(\mathbf{n}=95)$.

\begin{tabular}{|c|c|c|c|c|c|c|}
\hline \multirow[t]{2}{*}{ Variable } & \multicolumn{3}{|c|}{ Univariate analysis (OS) } & \multicolumn{3}{|c|}{ Multivariate analysis (OS) } \\
\hline & $\begin{array}{l}\text { Hazard } \\
\text { Ratio } \\
\end{array}$ & $\begin{array}{l}95 \% \text { confidence } \\
\text { interval }\end{array}$ & $p$ & $\begin{array}{l}\text { Hazard } \\
\text { Ratio } \\
\end{array}$ & $95 \%$ confidence interval & $p$ \\
\hline Age $\geq 44(\mathrm{VS} .<44)$ & 1.119 & 0.454 to 2.756 & 0.807 & 1.177 & 0.438 to 3.160 & 0.747 \\
\hline Gender Male vs. Female & 0.930 & 0.334 to 2.587 & 0.889 & 1.265 & 0.425 to 3.763 & 0.672 \\
\hline $\begin{array}{l}\text { Histopathologic characteristics } \\
\text { Undifferentiated carcinoma } \\
\text { (VS. others) }\end{array}$ & 0.048 & 0 to $1.636 \mathrm{E} 4$ & 0.640 & 0.000 & 0.000 & 0.987 \\
\hline $\begin{array}{l}\text { Lymph node status Positive } \\
\text { (VS. Negative) }\end{array}$ & 4.800 & 0.640 to 36.034 & 0.127 & 2.531 & 0.319 to 20.061 & 0.379 \\
\hline $\begin{array}{l}\text { Initial clinical stage III+IV (VS. } \\
\mathrm{I}+\mathrm{II})\end{array}$ & 2.284 & 0.665 to 7.847 & 0.190 & 2.226 & 0.338 to 14.667 & 0.406 \\
\hline Tumor stage $\mathrm{T}_{3}+\mathrm{T}_{4}\left(\mathrm{VS} . \mathrm{T}_{1}+\mathrm{T}_{2}\right)$ & 1.785 & 0.642 to 4.963 & 0.266 & 1.249 & 0.253 to 6.179 & 0.785 \\
\hline Recurrence Yes (VS. No ) & 2.553 & 0.842 to 7.741 & 0.098 & 1.143 & 0.353 to 3.700 & 0.824 \\
\hline Metastatic Yes (VS. No ) & 3.538 & 1.386 to 9.031 & 0.008 & 3.021 & 1.038 to 8.794 & 0.043 \\
\hline Skp2 High (Vs. No) & 10.122 & 2.931 to 34.952 & $<0.001$ & 8.215 & 2.236 to 30.172 & 0.002 \\
\hline
\end{tabular}

Table 4: Univariate and multivariate Cox-regression analysis for progression-free survival in NPC patients $(n=95)$.

\begin{tabular}{|l|l|l|l|l|l|l|}
\hline Variable & \multicolumn{2}{l|}{ Univariate analysis (PFS) } & \multicolumn{2}{l|}{ Multivariate analysis (PFS) } \\
\hline & $\begin{array}{l}\text { Hazard } \\
\text { Ratio }\end{array}$ & $\begin{array}{l}95 \% \text { confidence } \\
\text { interval }\end{array}$ & $\begin{array}{l}\text { Hazard } \\
\text { Ratio }\end{array}$ & $\begin{array}{l}95 \% \\
\text { interval }\end{array}$ \\
\hline Age $\geq 44$ (VS. $<44)$ & 1.334 & 0.693 to 2.568 & 0.389 & 1.630 & 0.758 to 3.506 \\
\hline Gender Male vs. Female & 0.869 & 0.408 to 1.852 & 0.716 & 1.541 & 0.686 to 3.463 \\
\hline $\begin{array}{l}\text { Histopathologic characteristics } \\
\text { Undifferentiated carcinoma (VS. } \\
\text { others) }\end{array}$ & 2.431 & 0.331 to 17.875 & 0.383 & 10.591 & 1.155 to 97.078 & 0.037 \\
\hline $\begin{array}{l}\text { Lymph node status Positive (VS. } \\
\text { Negative) }\end{array}$ & 10.460 & 1.430 to 76.513 & 0.027 & 3.730 & 0.485 to 25.684 & 0.206 \\
\hline $\begin{array}{l}\text { Initial clinical stage III+IV (VS. } \\
\text { I+II) }\end{array}$ & 1.915 & 0.836 to 4.388 & 0.124 & 1.276 & 0.376 to 4.325 \\
\hline Tumor stage T $+T_{4}\left(\right.$ VS. T $\left.+T_{2}\right)$ & 1.402 & 0.698 to 2.816 & 0.342 & 1.433 & 0.495 to 4.147 & 0.696 \\
\hline Recurrence Yes (VS. No ) & 7.138 & 3.370 to 15.120 & $<0.001$ & 6.000 & 2.541 to 14.165 & $<0.001$ \\
\hline Metastatic Yes (VS. No ) & 6.959 & 3.579 to 13.532 & $<0.001$ & 8.561 & 3.773 to 19.427 & $<0.001$ \\
\hline Skp2 High (Vs. No) & 5.160 & 2.472 to 10.771 & $<0.001$ & 3.488 & 1.463 to 8.317 & 0.005 \\
\hline
\end{tabular}

Furthermore, the recurrent rate in patients with high Skp2 was higher in the first 3 years than later on follow-up time (12.5\% versus $7.5 \%$, Table 2 ).

\section{High level of Skp2 indicates poor prognosis of NPC patients}

With the cutoff point determined by ROC curve analysis, we separated Skp2 expression into high group and low group. After the Kaplan-Meier survival analysis, we found that high level of Skp2 was a strong indicator for an inferior OS ( $<<0.001$, Fig 2 C) and PFS ( $<<0.001$, Fig 2D) in our patient cohort. The survival rate of patients with high and low levels of Skp2 were 60\% (24/40) versus $94.5 \%(52 / 55)$ for OS, and $75.6 \%$ (31/41) versus $98.1 \%$ $(53 / 54)$ for PFS respectively. In univariate analysis, high level of Skp2 predicted the poor OS ( $<<0.001$, Hazard Ratio $10.122,95 \%$ CI 2.931 to 34.952 , Table 3) and PFS $(\mathrm{p}<0.001$ Hazard Ratio 5.16, 95\% CI from 2.472 to 10.771 , Table 4) respectively. In multivariate analysis, Skp2 was also a significant predictor for poor OS ( $\mathrm{p}=0.002$, Hazard Ratio $8.215,95 \%$ CI from 2.236 to 30.172 , Table 3 ) and poor PFS ( $\mathrm{p}=0.005$, Hazard Ratio $3.488,95 \%$ CI from 
1.463 to 8.317 Table 4). Furthermore, recurrence and metastatic were also independent prognostic factors for PFS no matter from univariate or multivariate analysis $(p<0.001$, Table 4).

\section{Skp2 is high expressed in poor differentiated NPC cell lines}

Since Skp2 was a poor prognostic factor for NPC patients, we next sought to define its level in cellular level (Fig 3A). We found that Skp2 was relatively higher in poor-differentiated cell lines, including CNE2, Hone1, Sune1 as well as two other cell lines derived from CNE2, S26 and S18. While in well-differentiated cell lines (HK1 and CNE1), Skp2 expression was low especially in HK1 cells. We chose CNE2 and Hone1 for following
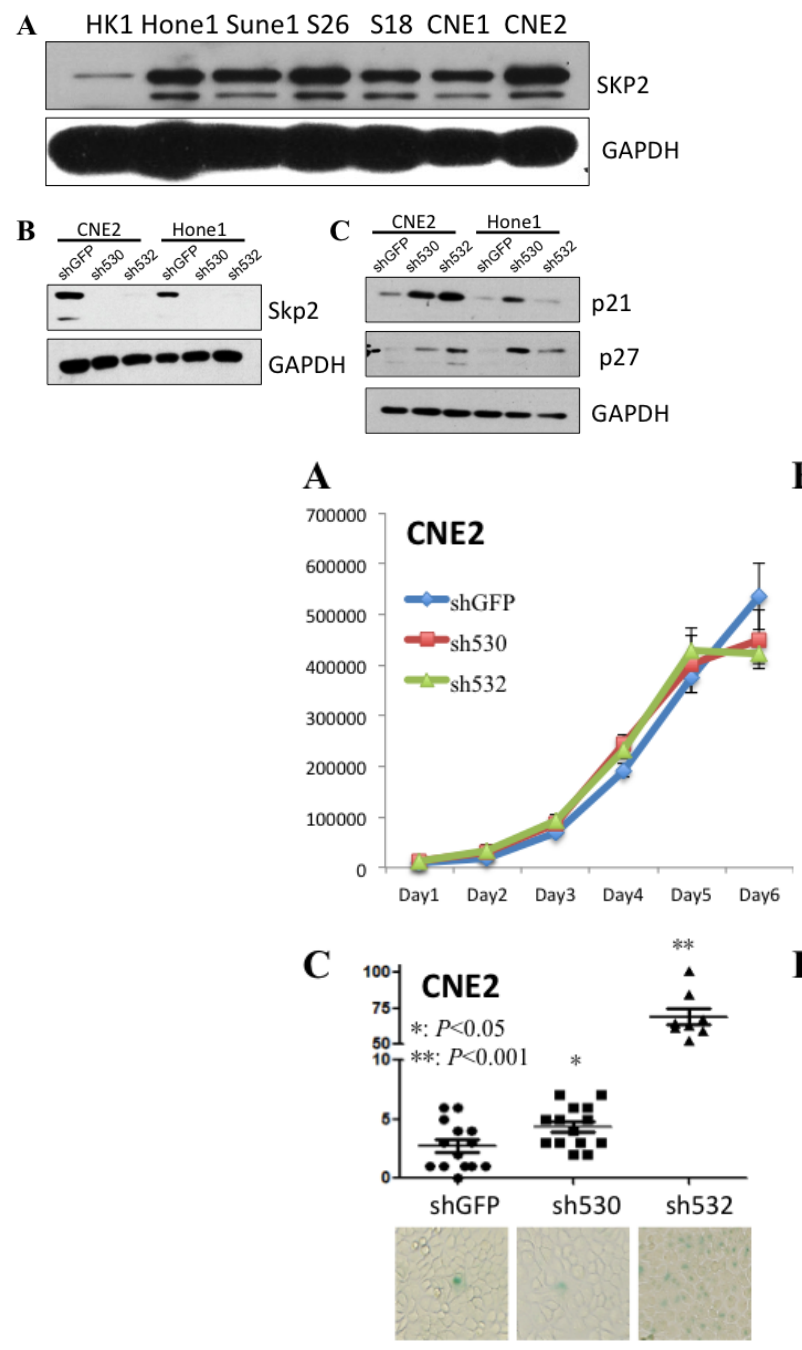

experiments since most of the NPC are poor-differentiated pathologically. To further study the role of Skp2 in NPC progression, we knocked down $S k p 2$ with two specific short hairpin RNAs (shRNAs) in CNE2 and Hone1 cells. The expression level of Skp2 was significantly reduced in both CNE2 and Hone1 cells compared with shGFP control (Fig 3B). In order to exclude off-target effect, we detected well-known downstream targets of Skp2, p21 $1^{\mathrm{Cip} / \mathrm{WAF}}$ and $\mathrm{p} 27^{\mathrm{Kip}}$, and found both of their levels were elevated upon Skp2 knocking down in CNE2 and Hone1 cells (Fig 3C).

\section{Skp2 inactivation partially reduces cell proliferation and triggers cellular senescence}

We next determined the role of Skp2 in NPC cell growth since it's a known cell cycle regulator. There was no significant change in the cell cycle profile of CNE2 and Hone1 cells after Skp2 knockdown (data not shown). However, inconsistent effects were found on CNE2 and Hone1 cells. For the cell proliferation study,

Figure 3: Skp2 expresses high in several NPC cell lines . A: Skp2 was highly expressed in poor-differentiated cell lines (Hone1, Sune1, S26, S18 and CNE2), but relatively low in well-differentiated cell lines (HK1 and CNE1). B: Skp2 was successfully knocked down in CNE2 and Hone1 cells compared with vector control. C: Both of $\mathrm{p} 21^{\mathrm{Cip} / \mathrm{WAF}}$ and $\mathrm{p} 27^{\mathrm{Kip}}$ were upregulated in CNE2 and Hone1 cells upon Skp2 knockdown.
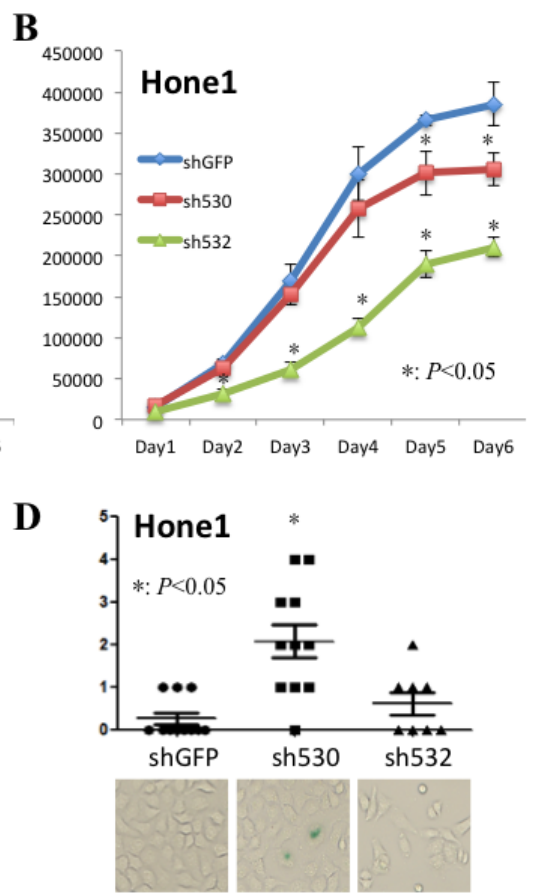

Figure 4: Skp2 deficiency partially reduces cell proliferation and triggers cell senescence . A, B: The cell proliferation rate did not change significantly upon $S k p 2$ knockdown in CNE2 cells, whereas decreased dramatically by both of the fragments in Hone1 cells, starting from the fifth and second day respectively $(*: p<0.05)$. C, D: Cellular senescence was enhanced by both of the knockdown fragments in CNE2 cells and only one of the fragments in Hone1 cells $(*: p<0.05, * * p<0.001)$, lower panels showed the cell images under bright field. 
there was no growth retardation after $S k p 2$ knockdown in CNE2 cell (Fig 4A). But in Hone1 cells, both of the knockdown fragments attenuated cell proliferation compared with control cells, the effect started from day 2 and day 5 respectively $(\mathrm{p}<0.05$, Fig 4B). Moreover, it has been reported that $S k p 2$ inactivation promotes the senescence of prostate cancer cells [19]. We then detected cell senescence and interestingly found that knockdown of Skp2 increased SA- $\beta$ Gal positive cells in both CNE2 and Hone1 cells: from $2.54 \pm 1.98$ per field to $4.36 \pm 1.74$ $(\mathrm{p}<0.05)$ and $68.88 \pm 15.89(\mathrm{p}<0.001)$ in CNE2 cells (Fig $4 \mathrm{C})$, from $0.27 \pm 0.47$ per field to $3.12 \pm 2.85(\mathrm{p}<0.05)$ in Hone 1 cells (one of fragment had no effect, $p>0.05,0.63$ \pm 0.22 ) (Fig 4D). Enhanced cellular senescence was also found in well-differentiated NPC cell line CNE1 without obvious cell proliferation retardation (Supplementary Fig S1). These findings indicated that although Skp2 does not play a universal role in all NPC cells lines, but indeed involves in cell proliferation and senescence.

\section{Knockdown Skp2 decreases CSC population and self-renewal ability}

Our previous report showed that $S k p 2$ inactivation leads to the reduction of ALDH1 positive cell frequency
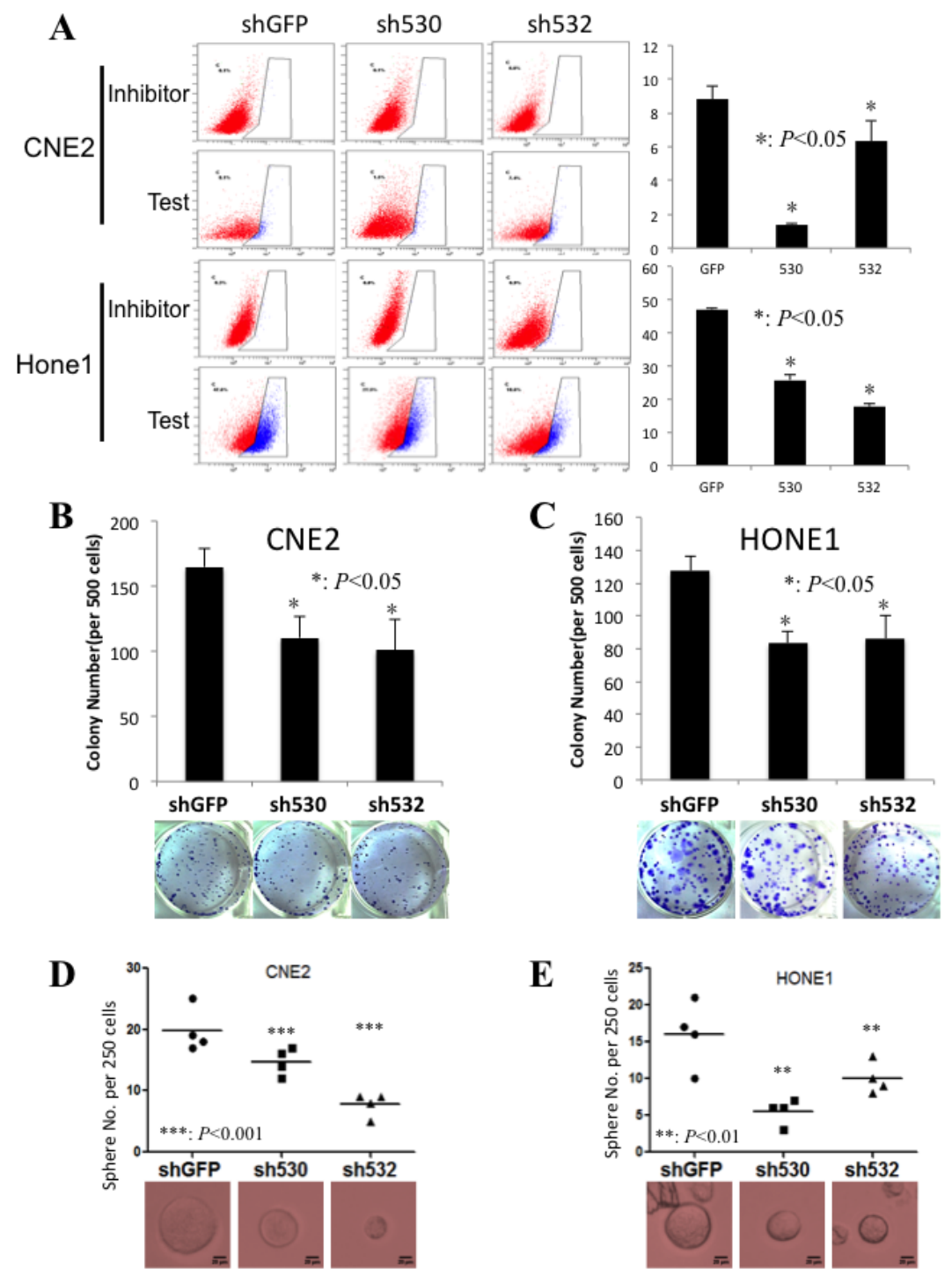

Figure 5: CSC population and the self-renewal ability decrease upon $\boldsymbol{S k p} 2$ knockdown. A: The ALDH1 positive stem cell frequency dropped dramatically in both CNE2 and Hone1 cells by two knockdown fragments comparing to control cells $(*$ : $<<0.05)$, left panel presents the flow cytometry profile and right panel displays the statistical results. B, C: The colony formation ability of both CNE2 and Hone1 cells decreased in Skp2 deficient cells (*: $\mathrm{p}<0.05)$, lower panels were the representative images of wells with colonies. D, E: The sphere formation ability was reduced significantly in both CNE2 (from19.76 \pm 3.6 to $14.75 \pm 2.22$ and 7.75 \pm 1.89 ) and Hone1 (from $12.25 \pm 1.71$ to $5.25 \pm 1.71$ and $4.75 \pm 1.71)$ cells upon $S k p 2$ knockdown $(* * *: \mathrm{p}<0.001$, **: $\mathrm{p}<0.01)$ 
and involves in the breast CSC maintenance[20]. We therefore detected ALDH1 positive NPC cells after $S k p 2$ knockdown. As expected, ALDH1 positive cell frequency were reduced from $8.8 \pm 0.75 \%$ to $1.4 \pm 0.1 \%(\mathrm{p}<0.001)$ and $6.3 \pm 1.21 \%(p<0.05)$ in CNE2, and from $46.93 \pm 0.76 \%$ to $25.83 \% \quad(\mathrm{p}<0.001)$ and $17.8 \pm 0.92 \% \quad(\mathrm{p}<0.001)$ in Hone1 upon Skp2 inactivation (Fig 5A). As an important characteristic of CSCs, self-renewal ability of cells was evaluated. The colony numbers from 500 cells on regular plate reduced from $166.67 \pm 14.5$ to $110.33 \pm 16.5$ and 101.0 \pm 23.26 in CNE2 (Fig 5B, p $<0.05$ ), while from $127.33 \pm 9.07$ to $83.33 \pm 6.80$ and $86.33 \pm 14.22$ in Hone 1 upon $S k p 2$ inactivation (Fig $5 \mathrm{C}, \mathrm{p}<0.05$ ). Furthermore, the sphere formation ability on low-attached plates was decrease dramatically from $19.76 \pm 3.6$ to $14.75 \pm 2.22$ and $7.75 \pm 1.89$ in CNE2 (Fig 5D, $\mathrm{p}<0.001$ ), from 12.25 \pm 1.71 to $5.25 \pm 1.71$ and $4.75 \pm 1.71$ in Honel (Fig 5E, $<<0.01$ ) and CNE1 (Supplementary Fig S2A). At the meanwhile, the anchorage independent colony formation ability was reduced significantly in CNE2 $(51.00 \pm 3.61$ to $29.00 \pm 4.58$ and 22.33 $\pm 6.03, \mathrm{p}<0.01$ ) (Supplementary Fig S2B). These data demonstrated that Skp2 involves in the maintenance of both pool size and self-renewal capacity of CSCs in NPC cell lines.

\section{DISCUSSION}

Skp2 is an important cell cycle regulator, which is widely studied in various cancer types. However, the role of Skp2 in NPC was seldom reported. ROC curve analysis is widely used clinically to evaluate sensitivity and specificity of diagnostic tests, the selected threshold (cut-off value) is useful for clinicians to make decision according to laboratory tests. The method has been proved to be reliable in tumor marker comparison [21]. We performed ROC curve analysis to establish a cut-off point in order to help the clinical diagnosis and treatment. In our patient cohort, Skp2 was an independent poor prognosis indicator for both OS and PFS. Furthermore, Skp2 predicted high recurrence and migration risk at the early stage of patients. Our result is consistent with previous reports that indicate the poor predictive role of Skp2 in NPC patients [22, 23].

As a cell cycle modulator, Skp2 deficiency is reported to slow down the cell proliferation in breast cancer, prostate cancer cells. However, there is no dramatic cell cycle arrest upon $S k p 2$ knockdown in NPC cell line CNE2 and Hone1. Literatures show that the oncogenic role of Skp2 always relies on the genetic status of PTEN, $\mathrm{ARF}, \mathrm{Rb}$ and other tumor suppression genes [19, 24]. However, the aberrant PTEN, P53 and Rb are not frequent in NPC [25], which might lead to the inconsistent outcome upon $S k p 2$ knockdown accompanied by reduction of $\mathrm{p} 21^{\mathrm{cip}}$ ${ }_{\mathrm{WAF}}$ and $\mathrm{p} 27^{\mathrm{Kip}}$. Further experiments are needed to delineate the role of Skp2 in the cell cycle regulation in NPC cells.

Cellular senescence is the status of permanent cell proliferation arrest which could be induced by eroded chromosome during repeated cell division and oncogenic stress [26]. Development of cellular senescence mostly depends on two fundamental tumor suppressor pathways ARF-p53 and p16-pRb. As our previous publication proved that $S k p 2$ silencing cooperated with PTEN inactivation and triggered cellular senescence by a p19 ${ }^{\text {Arf }}$-p53 independent pathway. Furthermore, levels of p21cip/WAF and p27Kip and Atf4 were induced after the inactivation of $S k p 2$. Knockdown of p21 cip/WAF and p27Kip and Atf4 reversed cellular senescence consistently, which confirmed that the upregulation of $\mathrm{p} 21 \mathrm{cip} / \mathrm{WAF}$ and p27Kip were required for the induction of cellular senescence upon $S k p 2$ knockdown [19]. We provided evidences in the current study that $S k p 2$ inactivation promoted the cellular senescence in NPC cell lines through p2 $1^{\text {cip/WAF }}$ and p $27^{\text {Kip }}$.

Cancer mass would relapse after most of non-CSC were killed by chemotherapy or radiotherapy due to the small amount of quiescent, high proliferate multipotent CSCs. In this study we found that knockdown Skp2 led to the reduction of stem cell like ALDH1 positive NPC cells. At the mean while, the self-renewal ability was decreased in $S k p 2$ deficient cells. Previous we show that Skp2 plays an important role in the maintenance of quiescence and self-renewal ability of hematopoietic stem cell[27]. Moreover, we find that $\beta$-catenin is downregulated in hematopoietic stem cells from $S k p 2$ knockout mouse, which subsequently attenuates the homing ability of hematopoietic stem cell [28]. Here we propose that $\beta$-catenin is the downstream executor of Skp2 to modulate the CSC in NPC cells. In deed the role of $\beta$-catenin in NPC CSC has been reported recently. The stem cell population increases in NPC cell line Hone1 upon enforced expression of $\beta$-catenin[29]. Another report shows that $\beta$-catenin is the downstream executor of EGFR/AKT regulated CSC property reservation in NPC cells[30]. Our future work will focus on deciphering the connection between $\beta$-catenin and Skp2 in the background of NPC.

Since Skp2 not only involves in the prognosis of NPC but also regulates the stem cell pool size and biological function of NPC cell line, we propose that Skp2 could be a potential target for NPC therapy. CSC target therapy in NPC has been shown promising outcome. Phenolic compounds resveratrol suppresses stemness of NPC CSCs[31], and the epithelial mesenchymal transition (EMT) which is considered as one of the origin of CSCs[32]. Nigericin, an antibiotic derived from Streptomyces hygroscopicus targets NPC CSC both in vitro and in vivo [33]. Recently, a specific Skp2 inhibitor is identified using high-throughput screening from large and diverse chemical libraries. This inhibitor selectively suppresses Skp2 E3 ligase activity, exhibits antitumor function in multiple animal models and reduces cancer survival combining with other chemotherapeutics[20]. 
Taken together, targeting Skp2 could benefit the patients by suppression of both CSCs and non-CSCs.

Our study provided evidences that Skp2 could serve as a poor prognosis marker not only for overall survival but also for recurrence and metastasis of NPC patients. We also emphasized the important role of Skp2 in NPC stem cell population and self-renewal capacity maintenance. Our finding might facilitate clinician in the future diagnosis and treatment of NPC patient.

\section{MATERIAL AND METHODS}

\section{Patients and cell lines}

NPC specimens were obtained from Departments of Nasopharynx undergoing nasal endoscopy at Sun Yatsen University Cancer Center (SYSUCC) with written informed consent $(n=95)$. Patients were diagnosed and classified by the Department of Pathology of SYSUCC following WHO guidelines. Age of patients ranged from 16 to 70 , averaged 43.8 years old. Human nasopharyngeal carcinoma cell lines CNE1, CNE2, S18, S26, Hone1, Sune1 and HK1 were from State Key Laboratory of Oncology in South China. CNE1, CNE2, S18, and S26 were maintained in RPMI1640 (Gibco) with 10\% fetal bovine serum (FBS, Gibco), Hone1, Sune1 and HK1 in RPMI1640 (Gibco) containing 10\% FBS (Hyclone). All cells were cultured in humidified incubator at $37^{\circ} \mathrm{C}, 5 \%$ $\mathrm{CO}_{2}$. Investigation has been conducted in accordance with the ethical standards and according to the Declaration of Helsinki and according to national and international guidelines and has been approved by the SYSUCC institutional review board.

\section{Follow-up}

All patients included in this study had follow-up records for over $5 \mathrm{y}$. After the completion of therapy, patients were observed at $3 \mathrm{~m}$ intervals during the first $3 \mathrm{y}$ and at $6 \mathrm{~m}$ intervals thereafter. The latest follow-up information was updated in January 2014. Overall survival (OS) was defined as the time from completion of therapy to the date of death or when censored at the latest date if patients were still alive; progression-free survival (PFS) was defined as the time from completion of therapy to the date of disease relapse/progression or the date of death or when censored at the latest date.

\section{Immunohistochemical (IHC) staining and evaluation}

IHC staining was performed as described previously [34]. In brief, after deparaffinization, rehydration, antigen retrieval, and blocking, slides were incubated overnight at $4{ }^{\circ} \mathrm{C}$ with monoclonal antibody against human $\mathrm{Skp} 2^{\mathrm{p} 45}$ (1:200; Invitrogen, USA) in a moist chamber. Next day the slides were incubated with secondary antibodies at room temperature for $30 \mathrm{~min}$. Then slides were stained with 3 , 3-diaminobenzidine and hematoxylin separately. Negative controls were achieved by replacing Skp2 antibody with corresponding non-immune serum immunoglobulin. The slides were scanned with the Nuance VIS-FL Multispectral Imaging System (Cambridge Research Instrumentation, Woburn, MA) following the vender's instructions. The signals were evaluated with Nuance 3.0 software referring to previous reports[35, 36].

\section{Receiver operating characteristic (ROC) curve analysis}

Being a reproducible method, ROC curve analysis has been applied to assess the tumor markers for diagnosis and prognosis prediction. Herein, we first used ROC curve analysis to select the cutoff point of Skp2 expression levels in our patient cohort for OS and PFS. In brief, the score localized closest to the point at both maximum sensitivity and specificity $(0.0,1.0)$ was selected as the cutoff score, leading to the greatest number of tumors which were correctly classified as having or not having the outcome. ROC curve analysis was facilitated by dichotomizing the features of patients' outcome into survival (death VS. others (censored, alive or death from other causes) and progression (local failure or distant metastasis).

\section{Viral infection}

$293 \mathrm{~T}$ cells were co-transfected with packaging plasmids p-Helper, p-Envelope and short hairpin RNA (shRNA) using Lipofectamine 2000 (Invitrogen, USA) to produce lentivirus particles according to manufacturer's instructions. Skp2 lentiviral shRNA sequences were reported before[37]. Supernatant from 293T cells were collected $48 \mathrm{hr}$ after transfection and applied to target cell. CNE2 and Hone1 cells were then selected by 1.5 $\mu \mathrm{g} / \mathrm{mL}$ puromycin two days after infection. Two weeks after selection, cell lysates were collected for Western Blot analysis to confirm the knockdown efficiency.

\section{Western blot assay}

Cells were harvested and lysed by RIPA lysis buffer (1\% NP-40, 1\% sodium deoxycholate, $0.1 \%$ SDS, $150 \mathrm{mM}$ $\mathrm{NaCl}$ and $10 \mathrm{mM} \mathrm{Na}_{2} \mathrm{HPO}_{4}, \mathrm{pH} 7.2$ ), supplemented with protease inhibitor cocktail (Roche, Mannheim, Germany). Immunoblotting was performed with standard protocols as previously described. The following antibodies were used: anti-Skp2 $2^{\mathrm{p} 45}$ (1:2000, Invitrogen), anti-p2 $1^{\mathrm{Cip} / \mathrm{WAF}}(1: 1000$, 
CST), anti-p27 ${ }^{\text {Kip }}(1: 1000$, CST), anti-GAPDH (1:10000, Protein Tec Group).

\section{Cell cycle profiles and proliferation analyses}

Cells were harvested, washed with pre-cold PBS, and fixed with ice cold $70 \%$ ethanol for at least $30 \mathrm{~min}$. Cells were then stained with propidium iodide $(50 \mathrm{mg} /$ $\mathrm{ml}$, Sigma) and $100 \mu \mathrm{L}$ RNase (1.0 mg/mL; Roche) for $30 \mathrm{~min}$ at $37^{\circ} \mathrm{C}$ against light and then were measured by flow cytometry. Cell proliferation was evaluated by cell counting. We seeded same amount of cells into 24-well plate and counted for six continuous days monitoring the cell growth (each day quadruplicate).

\section{Senescence-associated $\beta$-galactosidase Staining}

Cells were plated into 6-well plate at the concentration of $1 \times 10^{5}$ per well. After being cultured for around 3 to 4 days, cells were stained with Senescence Activated $\beta$-galactosidase (SA- $\beta$ Gal) Staining Kit (Beyotime, Guangzhou, China) following manufacturer's instructions. Then the green cells were observed under microscopy.

\section{Aldehyde Dehydrogenase 1 (ALDH1) positive cell detection}

The ALDH1 positive cell was detected using ALDEFLUOR assay kit (Stem Cell Technologies, Canada) following manufacturer's instruction. Briefly, cells were suspended in ALDEFLUOR assay buffer containing ALDH1 substrate and incubated $40 \mathrm{~min}$ at $37^{\circ} \mathrm{C}$. The aliquot of each sample cells was treated with $50 \mathrm{mmol}$ of specific inhibitor of ALDH1 (diethylaminobenzaldehyde) as negative control, according to which we set up gate. Then the positive cells were detected by a standard flow cytometer in the green fluorescence channel (520-540 nm). Propidium iodide was used before flow cytometer analysis to exclude dead cells.

\section{Colony formation assay}

Colony formation assay was performed according to procedures reported previously[10]. Briefly, cells were typsinized, resuspended into single cell supernatant, and then seeded into regular 6-well plates with 500 cells per well. After being cultured for about 14 days, the colonies were fixed with methanol and stained with crystal violet. Colonies with over 50 cells were counted.

\section{Sphere formation assay}

The sphere formation assay was followed with previous report[38]. Cells were seeded into ultralow attachment 24-well plate (corning), 250 cells per well. Cells were grown in a DMEM/F12 medium (Gibico), supplemented with B27 (Invitrogen), EGF (20 ng/ml), bFGF (20 ng/ ml, BD Biosciences), and heparin (0.5U/ $\mathrm{ml}$, Sigma). Fresh media were added (200ul/well) and the plates were gently shaked every other day. The spheres were counted after being cultured for 10 to 15 days.

\section{Soft agar colony formation assay}

The soft agar colony formation assays were performed according to the previous report [39]. Briefly, we re-suspended cells in medium containing $0.6 \%$ agarose (1,000 cells/well) and seeded into 6-well plate which was coated with $0.8 \%$ agarose. Then $2 \mathrm{ml}$ of culture media were added on the top in order to maintain the moisture and nutrient. After being cultured for about 2 to 3 weeks, the colonies were counted.

\section{Statistical Analysis}

The cutoff value of Skp2 signals for OS and PFS were assessed with ROC curve analysis. The relationships between Skp2 level and OS, PFS were evaluated with Kaplan-Meier survival analysis. The association between clinicopathologic factors and Skp2 level was evaluated using Chi-square test. The hazard ratios and 95\% confidence intervals for patient outcome were estimated by univariate and multivariate Cox regression. The data from in vitro study were expressed as mean \pm standard error. All $p$ values quoted were two sided and $p<0.05$ was considered statistically significant. Statistical analysis was performed with SPSS 16.0 (SPSS, Inc, Chicago, IL).

\section{Conflict of interest}

All authors claimed no conflict of interest.

\section{ACKNOWLEDGEMENTS}

We thank Dr. Hui-kuan Lin at MD Anderson Cancer Center for generously providing Skp2 shRNAs and useful technical supports. This study was supported by the National Natural Science Foundation of China (81101521), the National Science Research Program of China(2012CB967002), the Hong Kong Scholars Program (No. XJ2012059), the China Postdoctoral Science Foundation (No. 2013M540678) and the Fundamental Research Funds for Central Universities (No. 12ykpy52) to Jing Wang, the Scientific Research Foundation for the 
Returned Overseas Chinese Scholars to Su Guan.

\section{REFERENCES}

1. Barnes L, Eveson JW, Reichart P, Sidransky D, editors. Pathology and genetics of head and neck tumours. Lyon, France: IARC Press; 2005.

2. Wei W, Ayad NG, Wan Y, Zhang GJ, Kirschner MW, Kaelin WG, Jr.: Degradation of the SCF component Skp2 in cell-cycle phase G1 by the anaphase-promoting complex. Nature 2004, 428(6979):194-198.

3. Carrano AC, Eytan E, Hershko A, Pagano M: SKP2 is required for ubiquitin-mediated degradation of the CDK inhibitor p27. Nat Cell Biol 1999, 1(4):193-199.

4. Arbini AA, Greco M, Yao JL, Bourne P, Marra E, Hsieh JT, di Sant'agnese PA, Moro L: Skp2 overexpression is associated with loss of BRCA2 protein in human prostate cancer. Am J Pathol 2011, 178(5):2367-2376.

5. Wei Z, Jiang X, Liu F, Qiao H, Zhou B, Zhai B, Zhang L, Zhang X, Han L, Jiang H, Krissansen GW, Sun X: Downregulation of Skp2 inhibits the growth and metastasis of gastric cancer cells in vitro and in vivo. Tumour Biol 2013, 34(1):181-192.

6. Chan CH, Li CF, Yang WL, Gao Y, Lee SW, Feng Z, Huang HY, Tsai KK, Flores LG, Shao Y, Hazle JD, Yu D, Wei W et al: The Skp2-SCF E3 ligase regulates Akt ubiquitination, glycolysis, herceptin sensitivity, and tumorigenesis. Cell 2012, 149(5):1098-1111.

7. Meng J, Ding Y, Shen A, Yan M, He F, Ji H, Zou L, Liu Y, Wang Y, Lu X, Wang H: Overexpression of PPARgamma can down-regulate Skp2 expression in MDA-MB-231 breast tumor cells. Mol Cell Biochem 2010, 345(1-2):171180.

8. Huang Y, Tai AW, Tong S, Lok AS: HBV core promoter mutations promote cellular proliferation through E2F1mediated upregulation of S-phase kinase-associated protein 2 transcription. J Hepatol 2013, 58(6):1068-73.

9. Xu HM, Liang Y, Chen Q, Wu QN, Guo YM, Shen GP, Zhang RH, He ZW, Zeng YX, Xie FY, Kang TB: Correlation of Skp2 overexpression to prognosis of patients with nasopharyngeal carcinoma from South China. Chin J Cancer 2011, 30(3):204-212.

10. Wang J, Guo LP, Chen LZ, Zeng YX, Lu SH: Identification of cancer stem cell-like side population cells in human nasopharyngeal carcinoma cell line. Cancer Res 2007, 67(8):3716-3724.

11. Reya T, Morrison SJ, Clarke MF, Weissman IL: Stem cells, cancer, and cancer stem cells. Nature 2001, 414(6859):105111.

12. Visvader JE, Lindeman GJ: Cancer stem cells in solid tumours: accumulating evidence and unresolved questions. Nat Rev Cancer 2008, 8(10):755-768.

13. Wu A, Luo W, Zhang Q, Yang Z, Zhang G, Li S, Yao $\mathrm{K}$ : Aldehyde dehydrogenase 1, a functional marker for identifying cancer stem cells in human nasopharyngeal carcinoma. Cancer Lett 2013, 28; 330(2):181-189.

14. Yu F, Sim AC, Li C, Li Y, Zhao X, Wang DY, Loh KS: Identification of a subpopulation of nasopharyngeal carcinoma cells with cancer stem-like cell properties by high aldehyde dehydrogenase activity. Laryngoscope 2013, 123(8):1903-1911.

15. Su J, Xu XH, Huang Q, Lu MQ, Li DJ, Xue F, Yi F, Ren $\mathrm{JH}, \mathrm{Wu}$ YP: Identification of cancer stem-like CD44+ cells in human nasopharyngeal carcinoma cell line. Arch Med Res 2011, 42(1):15-21.

16. Janisiewicz AM, Shin JH, Murillo-Sauca O, Kwok S, Le QT, Kong C, Kaplan MJ, Sunwoo JB: CD44(+) cells have cancer stem cell-like properties in nasopharyngeal carcinoma. Int Forum Allergy Rhinol 2012, 2(6):465-470.

17. Lun SW, Cheung ST, Cheung PF, To KF, Woo JK, Choy KW, Chow C, Cheung CC, Chung GT, Cheng AS, Ko CW, Tsao SW, Busson P et al: CD44+ cancer stem-like cells in EBV-associated nasopharyngeal carcinoma. PLoS One 2012, 7(12):e52426.

18. Zhuang HW, Mo TT, Hou WJ, Xiong GX, Zhu XL, Fu QL, Wen WP: Biological characteristics of CD133(+) cells in nasopharyngeal carcinoma. Oncol Rep 2013, 30(1):57-63.

19. Lin HK, Chen Z, Wang G, Nardella C, Lee SW, Chan $\mathrm{CH}$, Yang WL, Wang J, Egia A, Nakayama KI, CordonCardo C, Teruya-Feldstein J, Pandolfi PP: Skp2 targeting suppresses tumorigenesis by Arf-p53-independent cellular senescence. Nature 2010, 464(7287):374-379.

20. Chan $\mathrm{CH}$, Morrow JK, Li CF, Gao Y, Jin G, Moten A, Stagg LJ, Ladbury JE, Cai Z, Xu D, Logothetis CJ, Hung MC, Zhang S et al: Pharmacological inactivation of Skp2 SCF ubiquitin ligase restricts cancer stem cell traits and cancer progression. Cell 2013, 154(3):556-568.

21. Pasanen PA, Eskelinen M, Partanen K, Pikkarainen P, Penttila I, Alhava E: Receiver operating characteristic (ROC) curve analysis of the tumour markers CEA, CA 50 and CA 242 in pancreatic cancer; results from a prospective study. Br J Cancer 1993, 67(4):852-855.

22. Xu HM, Liang Y, Chen Q, Wu QN, Guo YM, Shen GP, Zhang RH, He ZW, Zeng YX, Xie FY, Kang TB: Correlation of Skp2 overexpression to prognosis of patients with nasopharyngeal carcinoma from South China. Chin J Cancer 2011, 30(3):204-212.

23. Fang FM, Chien CY, Li CF, Shiu WY, Chen $\mathrm{CH}$, Huang HY: Effect of S-phase kinase-associated protein 2 expression on distant metastasis and survival in nasopharyngeal carcinoma patients. Int J Radiat Oncol Biol Phys 2009, 73(1):202-207.

24. Zhu L: Skp2 knockout reduces cell proliferation and mouse body size: and prevents cancer? Cell Res 2010, 20(6):605607.

25. Huang ZX, Yao KT: [Mining gene expression microarray data of nasopharyngeal carcinoma by literature profiling]. Di Yi Jun Yi Da Xue Xue Bao 2004, 24(7):798-801. 
26. Campisi J, d'Adda di Fagagna F: Cellular senescence: when bad things happen to good cells. Nat Rev Mol Cell Biol 2007, 8(9):729-740.

27. Wang J, Han F, Wu J, Lee SW, Chan CH, Wu CY, Yang WL, Gao Y, Zhang X, Jeong YS, Moten A, Samaniego F, Huang P et al: The role of Skp2 in hematopoietic stem cell quiescence, pool size, and self-renewal. Blood 2011, 118(20):5429-5438.

28. Wang J, Han F, Lee SW, Wu J, Chan CH, Zhang X, Gao Y, Su HK, Feng ZZ, Xu DZ, Lin HK: E3-ligase Skp2 regulates beta-catenin expression and maintains hematopoietic stem cell homing. Biochem Biophys Res Commun 2014, 14;445(3):566-71.

29. Cheng Y, Cheung AK, Ko JM, Phoon YP, Chiu PM, Lo PH, Waterman ML, Lung ML: Physiological beta-catenin signaling controls self-renewal networks and generation of stem-like cells from nasopharyngeal carcinoma. BMC Cell Biol 2013, 27;14:44.

30. Ma L, Zhang G, Miao XB, Deng XB, Wu Y, Liu Y, Jin ZR, Li XQ, Liu QZ, Sun DX, Testa JR, Yao KT, Xiao GH: Cancer stem-like cell properties are regulated by EGFR/ $\mathrm{AKT} /$ beta-catenin signaling and preferentially inhibited by gefitinib in nasopharyngeal carcinoma. FEBS J 2013, 280(9):2027-2041.

31. Shen YA, Lin CH, Chi WH, Wang CY, Hsieh YT, Wei YH, Chen YJ: Resveratrol Impedes the Stemness, EpithelialMesenchymal Transition, and Metabolic Reprogramming of Cancer Stem Cells in Nasopharyngeal Carcinoma through p53 Activation. Evid Based Complement Alternat Med 2013; 2013:590393.

32. Mani SA, Guo W, Liao MJ, Eaton EN, Ayyanan A, Zhou AY, Brooks M, Reinhard F, Zhang CC, Shipitsin M, Campbell LL, Polyak K, Brisken C et al: The epithelialmesenchymal transition generates cells with properties of stem cells. Cell 2008, 133(4):704-715.

33. Deng CC, Liang Y, Wu MS, Feng FT, Hu WR, Chen LZ, Feng QS, Bei JX, Zeng YX: Nigericin selectively targets cancer stem cells in nasopharyngeal carcinoma. Int J Biochem Cell Biol 2013, 45(9):1997-2006.

34. Zhou W, Yue C, Deng J, Hu R, Xu J, Feng L, Lan Q, Zhang W, Ji D, Wu J, Liu Q, Liu A: Autophagic protein Beclin 1 serves as an independent positive prognostic biomarker for non-small cell lung cancer. PLoS One 2013, 15; 8(11):e80338

35. Fiore C, Bailey D, Conlon N, Wu X, Martin N, Fiorentino M, Finn S, Fall K, Andersson SO, Andren O, Loda M, Flavin R: Utility of multispectral imaging in automated quantitative scoring of immunohistochemistry. J Clin Pathol 2012, 65(6):496-502.

36. Huang W, Hennrick K, Drew S: A colorful future of quantitative pathology: validation of Vectra technology using chromogenic multiplexed immunohistochemistry and prostate tissue microarrays. Hum Pathol 2013, 44(1):29-38.

37. Chan CH, Lee SW, Li CF, Wang J, Yang WL, Wu CY, Wu
J, Nakayama KI, Kang HY, Huang HY, Hung MC, Pandolfi PP, Lin HK: Deciphering the transcriptional complex critical for RhoA gene expression and cancer metastasis. Nat Cell Biol 2010, 12(5):457-467.

38. Dontu G, Abdallah WM, Foley JM, Jackson KW, Clarke MF, Kawamura MJ, Wicha MS: In vitro propagation and transcriptional profiling of human mammary stem/ progenitor cells. Genes Dev 2003, 17(10):1253-1270.

39. Bouska A, Lushnikova T, Plaza S, Eischen CM: Mdm2 promotes genetic instability and transformation independent of p53. Mol Cell Biol 2008, 28(15):4862-4874. 